\title{
Knowledge and Attitude Levels on Regenerative Endodontic Procedures among the Dental Residents in and around Puducherry
}

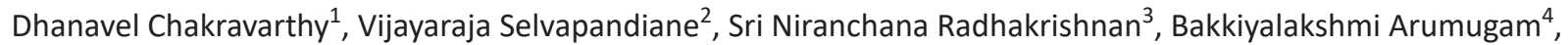 \\ Manonmani Shivakumar ${ }^{5}$
}

\begin{abstract}
Aim: To assess the knowledge and attitudes levels on regenerative endodontic procedures among dental residents in and around Puducherry. Materials and methods: It is a descriptive cross-sectional questionnaire-based study carried out in the region of in and around Puducherry in 2020. One hundred and ninety-three participants from five dental colleges included in this study: Adhiparasakthi Dental College and Hospital, $n=27$; Mahatma Gandhi Postgraduate Institute of Dental Sciences, $n=26$; Raja Muthiah Dental College and Hospital, $n=36$; Indira Gandhi Institute of Dental Sciences, $n=54$; and Sri Venkateswara Dental College and Hospital, $n=55$. A Questionnaire through the Google Form comprised a set of 18 questions.

Results: A total of $82.4 \%$ participants were aware of different types of regenerative endodontic procedures; $55.4 \%$ of the participants gained knowledge from curriculum; $28 \%$ of them gained knowledge through conference and journals; and $47.2 \%$ of them were aware of the different types of stem cells, of which only very few were able to identify all the possible cell sources (26.4\%) and possible teeth sources (20.7\%) from which the dental stem cells can be extracted.

Conclusion: Regenerative therapies are being one among the most novel topics, ruling the world of medicine and dentistry (7), it necessitates the inclusion of intensive training and more numbers of continuing dental education (CDE) programs to be conducted to uplift the standard of knowledge among the dental residents.

Keywords: Regenerative endodontics, Stem cells, Vitality.

Journal of Scientific Dentistry (2021): 10.5005/jp-journals-10083-1001
\end{abstract}

\section{INTRODUCTION}

Present treatment modalities offer high level of success in endodontics because of advancement in materials, instruments, and techniques. Even though the success rate is high, the end result of the endodontic treatment is devitalization of tooth (nonvital). The main disadvantage of the nonvital tooth is decreased biomechanical properties due to the loss of water. An ideal form of therapies should consist of regenerative approaches in which diseased or necrotic pulps are removed and replaced with the healthy pulp tissue which is regenerated to revitalize the tooth. ${ }^{1}$ In future, regenerative endodontic procedures (REPs) will play an unavoidable role in the field of dentistry to obtain a favorable and more predictable result. Hence, the familiarity about the REP for dentist emerging field is imperative. The aim of this survey is to assess the level of the knowledge and attitude levels regarding REPs among the dental residents in around and Puducherry and their enthusiasm in practicing. ${ }^{2}$

\section{Study Design, Locale, and Period}

This was a descriptive cross-sectional questionnaire-based study carried out in the region of in and around Puducherry in 2020. In this, the participants answered the questions related to their knowledge and attitude levels on REPs.

\section{Sampling and Methodology}

We used a purposive type of sampling containing 193 participants from five dental colleges in and around Puducherry.
${ }^{1-5}$ Department of Conservative Dentistry and Endodontics, Indira Gandhi Institute of Dental Sciences, SBV University, Puducherry, India

Corresponding Author: Bakkiyalakshmi Arumugam, Department of Conservative Dentistry and Endodontics, Indira Gandhi Institute of Dental Sciences, SBV University, Puducherry, India, Phone: +91 9677844822, e-mail: drbagyasenthil@gmail.com

How to cite this article:Chakravarthy D, SelvapandianeV, Radhakrishnan SN, Arumugam B, Shivakumar M. Knowledge and Attitude Levels on Regenerative Endodontic Procedures among the Dental Residents in and around Puducherry. J Sci Den 2021;11(2):44-47.

Source of support: Nil

Conflict of interest: None

The final sample comprised only the willing participants. Of the total 193 participants included in the study, female dental residents $(77.7 \%)$ were more than the male residents $(22.3 \%)$ (Table 1). The number of participants from each college was as follows: Adhiparasakthi Dental College and Hospital-27; Mahatma Gandhi Postgraduate Institute of Dental Sciences-26; Raja Muthiah Dental College and Hospital-36; Indira Gandhi Institute of Dental Sciences-54; and Sri Venkateswara Dental College and Hospital-55 (Table 2, Fig. 1).

A self-administered, validated questionnaire was used in this study. The questionnaire comprised three sections. First section consisted of questions regarding the demographic data of the 
Table 1: Gender

\begin{tabular}{lccc}
\hline & & Frequency & Percent \\
\hline \multirow{3}{*}{ Valid } & Female & 150 & 77.7 \\
& Male & 43 & 22.3 \\
& Total & 193 & 100.0 \\
\hline
\end{tabular}

Table 2: Name of the dental college

\begin{tabular}{|c|c|c|c|}
\hline & & Frequency & Percent \\
\hline \multirow{6}{*}{ Valid } & $\begin{array}{l}\text { Adhiparasakthi Dental College and } \\
\text { Hospital }\end{array}$ & 27 & 19.4 \\
\hline & $\begin{array}{l}\text { Indira Gandhi Institute of Dental } \\
\text { Sciences }\end{array}$ & 54 & 28.0 \\
\hline & $\begin{array}{l}\text { Mahathma Gandhi Postgraduate } \\
\text { Institute of Dental Sciences }\end{array}$ & 26 & 13.5 \\
\hline & $\begin{array}{l}\text { Rajah Muthiah Dental College and } \\
\text { Hospital }\end{array}$ & 36 & 18.7 \\
\hline & $\begin{array}{l}\text { Sri Venkateswara Dental College and } \\
\text { Hospital }\end{array}$ & 55 & 28.5 \\
\hline & Total & 198 & 100.0 \\
\hline
\end{tabular}

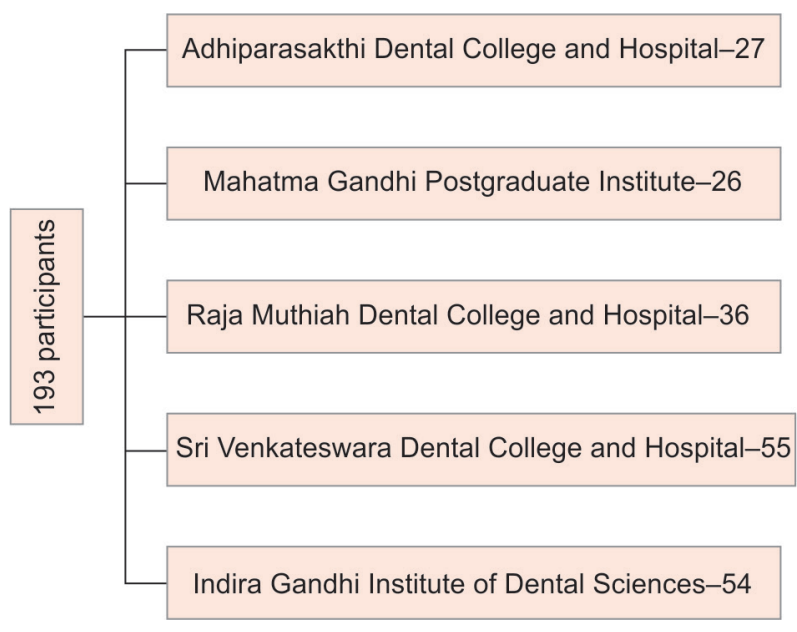

Fig. 1: Distribution of participants among groups

participants; the second section consisted of nine questions attributed to knowledge on REPs; and the third section consisted of nine questions attributed to attitude levels on REPs. Google Forms were constructed and circulated among the dental residents of the respective five dental colleges. Later, the data was obtained, and tabulations were made and subjected to descriptive analysis followed by statistical analysis. Microsoft Excel was used to manage the database (Tables 3 and 4).

\section{Result}

The result shows a majority of the participants (82.4\%) were aware of different types of regenerative endodontic procedures. The knowledge on REPs has been observed to be gained from curriculum (55.4\%) and conference and journals (28\%). Only $47.2 \%$ of the participants were aware of the different types of stem cells, of which, only very few were able to identify all the possible cell sources (26.4\%) and possible teeth sources (20.7\%) from which the dental stem cells can be extracted.

About $64.8 \%$ of the participants had no knowledge regarding various applications of dental stem cells. Barely $6.7 \%$ of the participants were only aware of the guidelines related to dental stem cells given by the Dental Council of Medical Research.

It is observed that $78.2 \%$ of the participants showed positive attitude on incorporating REPs into the dentistry. Nearly $59.1 \%$ of the participants believed that REPs would have a successful outcome, and $48.7 \%$ considered it to be a safe and reliable procedure. Even $72.5 \%$ of the participants were ready to save their teeth and dental tissues through stem cell banking, and $57.5 \%$ of them had idea of recommending their patients to preserve stem cells.

\section{Discussion}

Dental pulp is the loose connective tissue with unique characteristics of encased in a rigid unyielding environment, lack of collateral vascular supply, and it is potential to regenerate throughout the life. ${ }^{3}$ The secondary dentin or the reparative dentin, ${ }^{4}$ which up to a certain extent remains as a barrier to bacterial invasion, is formed on encounter of an injury or an external stimuli, ${ }^{5}$ but in case of severe infection, dental pulp is usually amputated and is replaced by an artificial material after disinfection of the pulp cavity. Although this helps in maintaining the tooth in the position, it still cannot preserve the vitality of the tooth. ${ }^{6}$ Newer technologies have come up with breakthrough therapies such as regenerative endodontic procedures to overcome this issue through stem cell biology and tissue engineering. ${ }^{7}$

Regenerative endodontics is founded on the seminal work of Dr Nygaard-Ostby, completed in 1960s. ${ }^{3}$ Regenerative endodontics aims at cell-based therapies, particularly stem cells to repair and regenerate damaged tissues or organs. Desired specialized cells or tissues are generated using various types of stem cells. ${ }^{7}$ Recently, mesenchymal stem cells have been identified in the dental pulp and are found to have the capacity to regenerate dental pulp complex even in the immature necrotic tooth. ${ }^{8}$

At present, the most common practice is administrating a scaffold of the same required new tissue shape that is seeded with stem cells. ${ }^{7-10}$ The supreme goal of regenerative therapies is to improve newer technologies so that restoration of lost, damaged, or aging tissues with newer tissues through regenerative and tissue engineering technologies by using either autologous or donated cells could be made possible. ${ }^{9}$

The evolution in dentistry have bestowed the dentists with the ability to efficiently retain, restore, and replace the teeth and other oral structures with improved technologies for the past 50 years. Now, it is high time to adapt to the novel technique of regeneration. ${ }^{10} \mathrm{~A}$ great clinical outcome is expected in endodontics on implementing biologic solutions for repair and regeneration of dental tissues. Apart from preserving the vitality of the pulp, it could even pave way for the regeneration of the pulp-dentinenamel-like tissue with the required form and function. ${ }^{11}$ Based on a survey, in the past decade, the dental practitioners have shown to readily acclimate themselves to most of the newer technologies. ${ }^{11,12}$ This present study remains as the first to collect data on the knowledge and attitude levels of the dental residents on REPs in and around Puducherry. 
Table 3: Questions regarding knowledge on REPs

\begin{tabular}{|c|c|c|c|}
\hline Questions & Options & Frequency & Percentage \\
\hline \multirow{3}{*}{$\begin{array}{l}\text { 1. Are you aware of different types of regenerative endodontic } \\
\text { procedures? }\end{array}$} & No & 34 & 17.6 \\
\hline & Yes & 159 & 82.4 \\
\hline & I have no knowledge regarding this & 32 & 16.6 \\
\hline \multirow{2}{*}{$\begin{array}{l}\text { 2. How did you gather knowledge about regenerative endodontic } \\
\text { procedure? }\end{array}$} & Through conferences and journals & 54 & 28.4 \\
\hline & Through curriculum & 107 & 55.4 \\
\hline \multirow{2}{*}{$\begin{array}{l}\text { 3. Have you or any of your relatives used umbilical cord or any other } \\
\text { types of stem cell banks? }\end{array}$} & No & 175 & 90.7 \\
\hline & Yes & 18 & 9.3 \\
\hline \multirow{2}{*}{ 4. Are you aware of different types of dental stem cells? } & No & 102 & 52.8 \\
\hline & Yes & 91 & 47.2 \\
\hline \multirow{2}{*}{ 5. Are you aware of the various applications of dental stem cells } & No & 125 & 64.8 \\
\hline & Yes & 68 & 35.2 \\
\hline \multirow{3}{*}{$\begin{array}{l}\text { 6. Are you aware of the guidelines related to dental stem cells given by } \\
\text { the Indian Council of Medical Research? }\end{array}$} & May be & 44 & 22.8 \\
\hline & No & 136 & 70.5 \\
\hline & Yes & 13 & 6.7 \\
\hline
\end{tabular}

Table 4: Questions regarding attitude toward REPs

\begin{tabular}{|c|c|c|c|}
\hline Questions & Options & Frequency & Percentage \\
\hline \multirow{3}{*}{ 1. Should regenerative therapy be incorporated into the dentistry? } & Maybe & 38 & 19.7 \\
\hline & No & 4 & 2.1 \\
\hline & Yes & 151 & 78.2 \\
\hline \multirow{3}{*}{$\begin{array}{l}\text { 2. Do you think regenerative endodontic procedure would have } \\
\text { successful outcome? }\end{array}$} & Maybe & 76 & 39.4 \\
\hline & No & 3 & 1.6 \\
\hline & Yes & 114 & 59.1 \\
\hline \multirow{3}{*}{$\begin{array}{l}\text { 3. Will you be willing to save teeth and dental tissues for stem cell } \\
\text { banking? }\end{array}$} & Maybe & 46 & 23.8 \\
\hline & No & 7 & 3.6 \\
\hline & Yes & 140 & 72.5 \\
\hline \multirow{3}{*}{$\begin{array}{l}\text { 4. In your clinical practice, will you recommend or advise your } \\
\text { patients to store/preserve dental stem cells? }\end{array}$} & Maybe & 75 & 38.9 \\
\hline & No & 7 & 3.6 \\
\hline & Yes & 111 & 57.5 \\
\hline \multirow{3}{*}{$\begin{array}{l}\text { 5. What would make you most likely to recommend stem cell and } \\
\text { regenerative dental treatment to your patients? }\end{array}$} & It is the most effective treatment option & 83 & 43 \\
\hline & It is safe and reliable & 94 & 48.7 \\
\hline & I would never recommend it & 16 & 8.3 \\
\hline \multirow{4}{*}{$\begin{array}{l}\text { 6. Which of the following do you feel will be a hindrance in imple- } \\
\text { menting regenerative endodontic procedures in your practice? }\end{array}$} & High cost and resulting financial burden & 53 & 27.5 \\
\hline & Low availability of products & 22 & 11.4 \\
\hline & Poor patient compliance & 16 & 8.3 \\
\hline & All the above & 102 & 52.8 \\
\hline \multirow{3}{*}{$\begin{array}{l}\text { 7. Have you attended any workshop/conference/seminar or continu- } \\
\text { ing dental education program about the applications of stem cells? }\end{array}$} & No & 160 & 82.9 \\
\hline & Yes & 33 & 17.1 \\
\hline & Maybe & 73 & 37.8 \\
\hline \multirow{2}{*}{$\begin{array}{l}\text { 8. Do you believe that dental professional association should regulate } \\
\text { the use of stem cell and regenerative dentistry? }\end{array}$} & No & 5 & 2.6 \\
\hline & Yes & 115 & 59.6 \\
\hline \multirow{2}{*}{$\begin{array}{l}\text { 9. In future, are you interested to attend any workshop/conference/ } \\
\text { seminar or continuing dental education program about the applica- } \\
\text { tions of stem cells? }\end{array}$} & No & 11 & 57 \\
\hline & Yes & 182 & 94.3 \\
\hline
\end{tabular}

A majority (82.4\%) of the dental residents were already aware of the various REPs, which was in coordinate with similar studies by Ajay et al., Chitroda et al., Nitha et al., and Aishwarya Das et al., 2,13-15 In the orofacial region, there are various sources of dental stem cells such as dental pulp stem cells, dental follicle stem cells, and stem cells of apical papilla, periodontal ligament stem cells, tooth germ progenitor cells and immature dental pulp cells. A majority of the participants were able to identify more than one source of dental stem cells which was in accordance with the study by Chitroda et al. ${ }^{14}$ Although many were aware of the supremacy of stem cells, barely $9.3 \%$ of the participants were engaged in the umbilical cord or other types of stem cell banking. Many of the participants $(64.8 \%)$ remained unaware of the various application of dental stem cells. In contrary, in the study conducted by Chitroda et al. and Sede et al., it was observed that an awareness of $53.9 \%$ and $81 \%$, respectively, was present. ${ }^{14,16}$ This might be because their study population comprised dental professionals who would have had better exposure through dental practice and conferences. ${ }^{16}$

It is observed that half the participants (55.4\%) considered that they gathered knowledge through curriculum which is in accordance with the study by Aishwarya Das et al. ${ }^{2}$ According to Sede et al., the primary source of information was seen to be 
from the conference, symposium, or seminar. ${ }^{16}$ Contradicting the above stated information, $82.9 \%$ of the participants in our study have responded that they have never attended any conference, symposium, seminar, or CDE programs regarding REPs.

The above-mentioned information indicates a hindrance among the participants to implement their knowledge into practice although they have a positive attitude toward REPs. The major hindrances found in practicing REPs in the dentistry were seen to be high cost and resulting financial burdens, low-availability of products, and poor patient compliance; comparable results were found in survey performed by Chitroda et al., Nitha Jose, Goyal et al., and Epelman et al. ${ }^{14,15,17,18}$ Besides these hinderances, the number of participants who considered REPs as the most effective treatment option and safe were $43 \%$ and $48.7 \%$, respectively, but about $70.5 \%$ were unaware of the guidelines related to dental stem cells given by the Indian Council of Medical Research. A majority of the participants (94.5\%) showed interest in attending CDE programs related to REPs, and most (59.6\%) believed that the dental professional association should regulate the use of stem cells in dentistry. This shows a gap prevailing in between the attitude toward REPs and their in-depth knowledge on REPs among the dental residents.

\section{Conclusion}

The prevailing dental curriculum lacks a proper constructed method to educate the undergraduates with more of newer scientific advancements such as REPs. It is utmost vital for the future dentists to have a good in-depth knowledge on regenerative therapies. In this study, about $94.5 \%$ were readily willing to expand their knowledge on REPs. As regenerative therapies are being one among the most novel topics ruling the world of the medicine and dentistry, ${ }^{15}$ it necessitates the inclusion of intensive training and more numbers of CDE programs to be conducted to uplift the standard of knowledge among the dental residents.

\section{References}

1. Utneja S, Nawal RR, Ansari MI, Talwar S, Verma M. A survey of attitude and opinions of endodontic residents towards regenerative endodontics. J Conserv Dent 2013;16(4):314. DOI: 10.4103/09720707.114357.

2. Das A, Nasim I. A knowledge, attitude, and practice survey among endodontic postgraduate students toward regenerative endodontic procedures. Drug Invent Today 2019;12(5).

3. Estrela C, Holland R, Estrela CR, Alencar AH, Sousa-Neto MD, Pécora JD. Characterization of successful root canal treatment. Braz Dent J 2014;25(1):3-11. DOI: 10.1590/0103-6440201302356.
4. Bleicher F, Richard B, Thivichon-Prince B, Farges JC, Carrouel F. Odontoblasts and dentin formation. In: Stem cell biology and tissue engineering in dental sciences. Academic Press; 2015. p. 379-395.

5. Hargreaves KM, Cohen S, Berman LH. Cohen's pathways of the pulp. Mosby Elsevier; 2011.

6. Murray PE, Garcia-Godoy F, Hargreaves KM. Regenerative endodontics: a review of current status and a call for action. J Endod 2007;33(4):377-390. DOI: 10.1016/j.joen.2006.09.013.

7. Yamada $Y$, Ueda M, Hibi H, Nagasaka T. Translational research for injectable tissue-engineered bone regeneration using mesenchymal stem cells and platelet-rich plasma: from basic research to clinical case study. Cell Transplant 2004;13(4):343-356. DOI: $10.3727 / 000000004783983909$.

8. Yamada Y, Ueda M, Naiki T, Takahashi M, Hata KI, Nagasaka T. Autogenous injectable bone for regeneration with mesenchymal stem cells and platelet-rich plasma: tissue-engineered bone regeneration. Tissue Eng 2004;10(5-6):955-964. DOI: 10.1089/1076327041348284.

9. Murray PE, Garcia-Godoy F. Stem cell responses in tooth regeneration. Stem Cells Dev 2004;13(3):255-262. DOI: 10.1089/154732804323099181.

10. Laino G, Graziano A, d'Aquino R, Pirozzi G, Lanza V, Valiante S, et al. An approachable human adult stem cell source for hard-tissue engineering. J Cell Physiol 2006;206(3):693-701. DOI: 10.1002/ jсp.20526.

11. Ez-Abadi AR, Ahmady AE, Tabatabaei FS. Dental residents' knowledge and attitude towards stem cells and regenerative dentistry. J Dent School 2017;35(3):99-107. DOI: 10.22037/jds.v35i3.24598.

12. Goswami M, Kumar G, Sharma S. "Dental Stem Cells": awareness, knowledge, and attitude of dental professionals - a cross-sectional study. Spec Care Dentist 2020;40(1):90-96. DOI: 10.1111/scd.12442.

13. Ajayi Deborah M, Imf A, Olaide GS, Abu A. A survey of knowledge and practice of regenerative endodontics among Nigerian dental residents. Int J Sci Basic Appl Res 2014;14(1):75-85.

14. Chitroda PK, Katti G, Attar NM, Shahbaz S, Sreenivasarao G, Patil A. Stem cells in dentistry: A study regarding awareness of stem cells among dental professionals. Indian J Dent Res 2017;28(6):711-716. DOI: 10.4103/ijdr.IJDR_771_16.

15. Jose N. Assessment of knowledge, attitude, and practice regarding applications of stem cells in dentistry among dental house surgeons, postgraduate students, and teaching faculties in two dental colleges in Ernakulam, Kerala, India. Int J Oral Care Res 2018;6(1):65-68. DOI: 10.5005/jp-journals-10051-0151.

16. Sede MA, Audu O, Azodo CC. Stem cells in dentistry: knowledge and attitude of Nigerian dentists. BMC Oral Health 2013;13(1):1-8. DOI: 10.1186/1472-6831-13-27.

17. Goyal A. Knowledge, awareness and attitude regarding stem cells among dental practitioners in Udaipur city, Rajasthan. Int J Adv Res 2015;3:677-684.

18. Epelman I, Murray PE, Garcia-Godoy F, Kuttler S, Namerow KN. A practitioner survey of opinions toward regenerative endodontics. J Endod 2009;35(9):1204-1210. DOI: 10.1016/j.joen.2009.04.059. 